
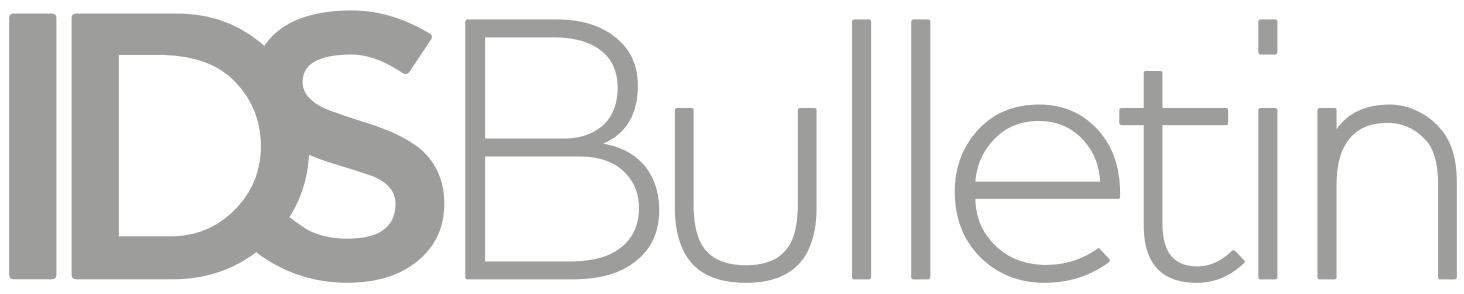

Transforming Development Knowledge

ARCHIVE COLLECTION

Volume 49 | Number 1A | April 2018

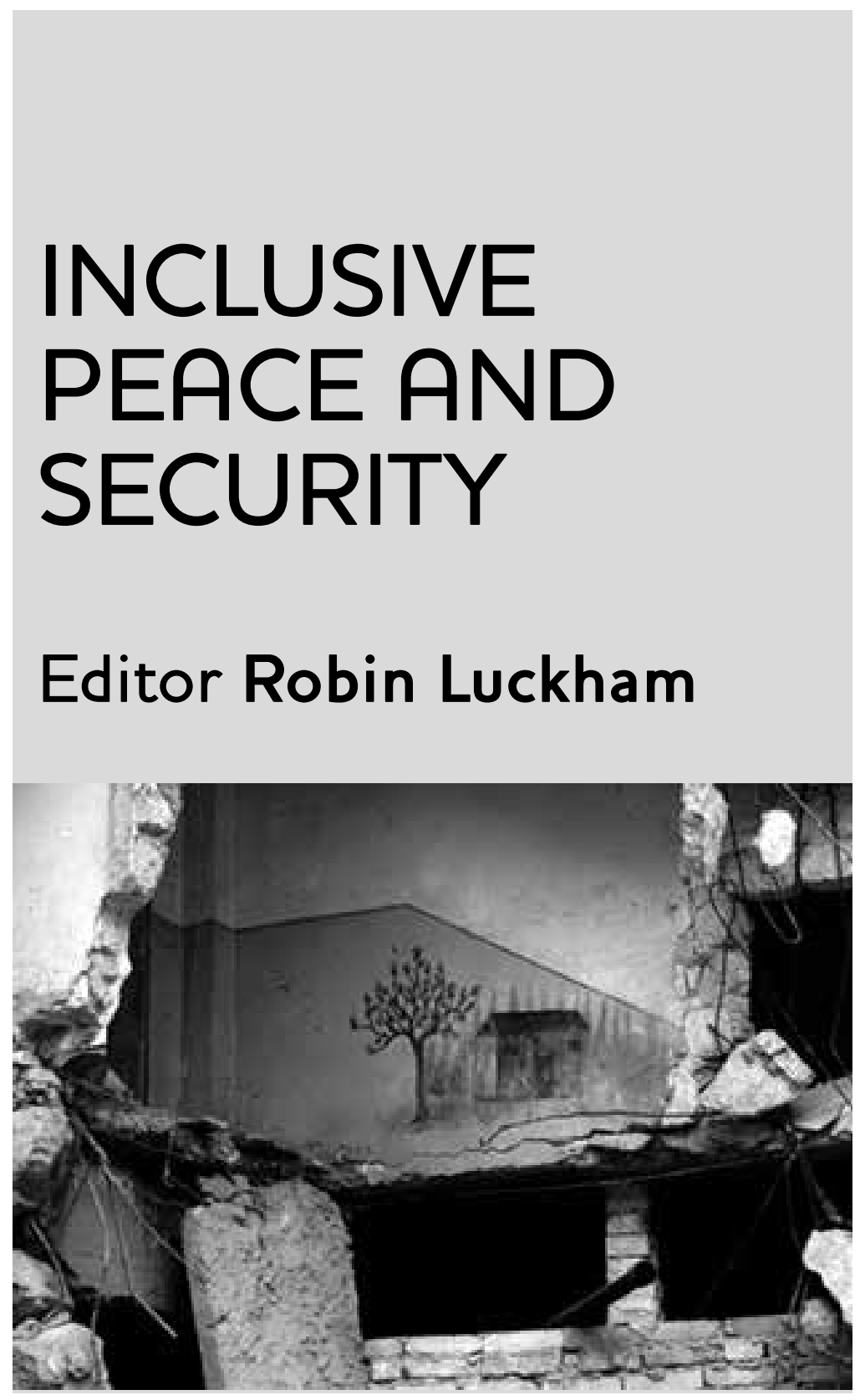




\section{Contents}

From Disarmament and Development to Inclusive Peace and Security: Four Decades of IDS Research

Robin Luckham

Article first published April 2018, IDSB49.1A

Peace and Development

Willy Brandt

Article first published October 1985, IDSB16.4

Editorial: Disarmament and Development - the International Context

Robin Luckham

Article first published October 1985, IDSB16.4

Globalism Versus Villagism: Food Security and Environment at National and International Levels

Susanna Davies and Melissa Leach

Article first published July 1991, IDSB22.3

War and Famine in Africa

Alex de Waal

Article first published October 1993, IDSB24.4

Insecurity, Conflict and the New Global Disorder

Susan Willett

Article first published May 2001, IDSB32.2

Peace Through Agrarian Justice

Paul Richards and Khadija Bah

Article first published June 2005, IDSB36.2

'Security from Below' in Contexts of Chronic Violence

Alexandra Abello Colak and Jenny Pearce Article first published March 2009, IDSB40.2

Gendering the New Security Paradigm in Sri Lanka

Neloufer de Mel

Article first published March 2009, IDSB40.2

\section{Researching the Gendered Silences of Violence in El Salvador}

Mo Hume

Article first published May 2009, IDSB40.3

Quantitative Methods in Contexts of Everyday Violence

Patricia Justino, Jennifer Leavy and Elsa Valli Article first published May 2009, IDSB40.3

Crime and Social Cohesion in the Time of Crisis: Early Evidence of Wider

Impacts of Food, Fuel and Financial Shocks

Naomi Hossain

Article first published September 2009, IDSB40.5

Social Contracts, Networks and Security in Tropical Africa Conflict States:

An Overview

David K. Leonard

Article first published January 2013, IDSB44.1

This article has been reissued as part of IDS Bulletin Archive Collection Vol. 49 No. 1 A April 2018: ‘Inclusive Peace and Security’; the Introduction is also recommended reading. 


\title{
Researching the Gendered Silences of Violence in EI Salvador
}

\author{
Mo Hume
}

Abstract All research on violence is informed by silences. In practical terms, an immediate reading of silence may be that it presents an obstacle for the researcher who is dependent on people who are willing to speak out. Another interpretation of silence is that its presence is central to what we know about violence. Silence and the invisibility of gender in mainstream analyses of violence are closely connected. This article reflects on research in El Salvador, arguing that a critical analysis of violence should directly confront the effects of silence and silencing, particularly as they concern violence against women, which is often separated from 'real' violence. It discusses the excuses and localised rationales that work to silence women's experiences of abuse.

No, you keep quiet because you're afraid, right? For fear of things because you have kids and they are out and about, they go to the [football] pitch to play [...] My son goes to work at night and you know that you can't, well, for fear that they might do something to your [loved ones], you know? So even though, erm, you know things, no one speaks about it because the truth is that with those men, well, you are afraid because they don't mess around before they hurt your family. That's the type offear that comes from speaking about things, so although you know what's going on, you say nothing because you are afraid.

Anon. woman, Soyapango, 2002

In the above quote, an inhabitant of a lowincome community on the outskirts of El Salvador's capital city, San Salvador, uncovers some of the tensions in speaking about violence in her locality. Her words indicate how silence is both productive of and symptomatic of the fear and ever-present threat of violence. All research on violence is informed by silences, whether this is discussed explicitly or not. In practical terms, an immediate reading of silence may be that it presents an obstacle for the researcher who is dependent on people who are willing to speak out. Such a reading positions silence as restricting knowledge about violence and actively undermining efforts to challenge it. While this is certainly the case, a less obvious, but no less pertinent, interpretation of silence is that its presence is central to what we know about violence. Rather than an obstacle to be surmounted, silence can be a useful starting point from which to generate critical perspectives on and, therefore, challenge normative understandings of violence that appear as unquestionable truths.

Reflecting on two periods of research in El Salvador, ${ }^{1}$ I argue that a critical analysis of violence should confront directly the effects of silence and silencing. Informed by central questions of feminism, I explore this issue in three ways. First, I address how institutions undermine not only what we (can) know about violence, but also responses to it. Second, I explore how men deflect attention away from their use of violence by invoking widely accepted excuses and blaming women. This takes us to the final point which argues that as long as men and masculinities remain ignored in most analyses of violence, our knowledge remains limited, and normative understandings of violence that fail to uncritically unpack and problematise its masculinised dimensions are privileged. In other words, it becomes so conventional to speak about (public) violence in terms of murderers, gang members and so on, that the gendered character of the violence merits no scrutiny and is not subject to research. Before I engage in this analysis, I will offer a brief overview of my 
approach to the research and introduce some reflections on my understanding of silence.

\section{Situating a feminist analysis of silence in El Salvador}

El Salvador underwent a brutal civil war from 1980 to 1992 and its peace remains characterised by violence and insecurity. Despite much international focus on the country as a positive example of negotiated resolution of armed conflict, the dividends of 'peace' in El Salvador have been largely 'negative' for the country's poor, since little attention has been paid to addressing structural inequalities and poverty (Pearce 1998). Since the cessation of the war, the country continues to demonstrate one of the highest rates of violent crime in the world (FESPAD 2008). Less visible are the high levels of violence in the home that predominantly affect women and children. There are little reliable data about domestic abuse and sexual crimes, which are characterised by silence and under-reporting. In effect, a separation of violence between public and private spheres renders such violence a public secret. People know it exists, even expect it and accept it. Yet, it is rarely singled out for attention in wider debates on citizen security (Hume 2004), with public discussion limited to the women's movement and international organisations.

It is precisely the invisibility of gender in mainstream analyses of violence - both popular and academic - that shaped my research questions. I worked for a Salvadoran feminist NGO from 1997 until 2000, and witnessing the struggles of women in confronting violence in their public and private lives inspired my research questions. Living in El Salvador, it is impossible to escape the everyday panic about issues of security. People speak about crime constantly and often have a story to tell about personal experiences or those of family members and friends. Caldeira (2000: 19-20) argues that 'talk of crime' produces particular understandings of crime that both reproduce and magnify actual problems. Much of it is implicitly about certain types of crime by certain types of people, reinforcing normative and highly discriminatory understandings of violence. It is almost exclusively about crimes that take place in the public sphere. The more I listened to the stories of my research participants, the more aware I became of the complex and often conflicting ways in which people spoke about different types of violence in their daily lives. I also became aware of what people did not say and how humour, tears and silence combine in the stories people tell about violence. Listening critically to these discursive practices awakened me to different meanings of violence, and alerted me to the importance of local and euphemistic vocabularies. The exaggeration of specific acts of violence was often juxtaposed with the minimisation of certain behaviours. The degree of harm seemed in many instances to be incidental to the interpretation offered. In the noise about violence and crime, certain versions dominate, leaving little room for alternative stories. The effect of this is to silence marginal voices, such as women, the poor and young people who struggle to find a space to articulate their fears and concerns.

It is against the silencing of particular voices that feminism, post-colonialism and subaltern studies have emerged. These critical research approaches confront the effects of silencing on the way knowledge is produced. Addressing the silencing of women's experiences has been a unifying concern for feminists for decades (Aretxaga 1997). ${ }^{2}$ Widely understood as research 'on women, for women', feminist research has always engaged with and problematised issues of male power and violence. Feminist activists and scholars have campaigned on the importance of naming violence and uncovering its 'hidden' dimensions (Kelly and Radford 1990; Kelly 1988). A central task of this feminist project has been to explode the widely held 'silences' that both inform and limit what we know about violence. It follows, therefore, that it is an essential task for the committed researcher to 'listen' out and think about these in a critical manner. In this vein, I argue here that silence should be understood not just in terms of what is not said but also in terms of how people speak about violence and what they are 'allowed' to say (Foucault 1980: 27).

\section{The limits of public knowledge and response: silencing gender}

Accessing basic data on violence is a challenge. Accessing data that are disaggregated by gender is even more so. Although both access and quality have improved, data collection on violence is inadequate and different state bodies maintain contradictory databases for each crime (Cruz et al. 1999). Although I have found accessing public 
registers more straightforward today than even five years ago, ${ }^{3}$ it remains a challenge to find local or gender-disaggregated data. Accessing basic information is difficult from outside state bodies, but even the sharing of information between agencies cannot be taken for granted. One civil servant spoke of 'institutional jealousy' with regard to the sharing of statistics (Interview, October 2007). As in other contexts, the silencing and manipulation of data on violence also serves the political purpose of justifying or limiting certain policy initiatives (Shrader 2001).

Important information is collected at the moment of recording details of a violent incident, but mechanisms to transfer data from local to national levels tend to aggregate basic data on age and gender at the local level, thus losing important details for analysis. For example, Oxfam America (2007) show that information on the sex of the victim in rape cases is often recorded as 'unknown'. This gap hides important gender dynamics of certain types of violence, and it also contributes to misinformation on the scale of non-lethal violence. Jackson (2006) suggests that research on gender issues is often required to present more evidence than 'mainstream' research. If even the most basic evidence is difficult to come by, this makes the task of analysing the gendered dynamics of violence all the more difficult.

Linked to this is the huge problem of underreporting of crimes, especially gendered violence. Lack of information about rights and processes, misinformation or indeed partisan politics at a local institutional level can have a deterrent effect on citizens reporting violence. One man in Soyapango suggested that for a poor person to report a crime was as futile an exercise as 'throwing salt into the sea' (February 2002). A group of women in San Marcos suggest that state agencies are highly partisan, and the degree of attention you receive depends largely on who you know. Even officials acknowledged that it was important to 'recommend' women to other institutions in order for them to be treated well (Interviews, October and December 2007). Important here is the perception. The perceived association of personal or party political connections with state agencies silences attempts to access services. In turn, this risks undermining attempts between state and civil society groups to forge pathways out of violence.
Another important obstacle to addressing violence against women is the high level of institutionalised patriarchy that serves to reinforce male impunity. In a focus group in San Marcos (October 2007), women suggested that they face a double threat. Police invoke patriarchal notions of the 'ideal-type' family to dissuade women from pressing charges against the 'father of your children'. In return, men 'punish' women for speaking out:

You call the police but all the police do is say 'so Missus, your husband hit you then? But he's your husband, the father of your children, are you going to leave your kids without a father? No? OK then, forgive him and let him in'.

Is that what the police say?

Yes, and the husband says: 'Why did you put the cops on me?' and beats her up again. That's the reality; he hits us and we can't do anything about it.

This vignette exposes how levels of institutional collusion with men actively limit the options available to women. In order to speak out and to challenge these normative, gendered frameworks, women must feel safe. Despite local authorities' legal remit, the fact that women perceive them as protective of male privilege actively dissuades women from speaking out and seeking justice. The context of wider violence means that local authorities are overwhelmed, under-resourced and unable to cope with the levels of violence in society. A group of women from Soyapango, interviewed in March 2002, indicated that they would not intervene in cases of violence in the home for fear of what might happen to them: 'We are afraid to call the police because they might see you and thump you'. When I asked a group of women in San Marcos in October 2007 how they respond in cases of violence against women, they replied:

Advise her, give her advice [on what to do].

Advise her? Anything else?

See if the institutions ... orient her, help her.

And if she is a member of your family?

Support her, accompany her too.

And if she is a neighbour? 
See what you can do for her; take her to an institution that can help her.

So the community gets involved if there is a case of domestic abuse, everyone realises it is happening?

First you call the police, and then you help her.

One of the most basic lessons of social research is that respondents often offer researchers the answers they think they want to hear, rather than what corresponds to usual practice. The conversation continues:

I have a question, is that what you actually do or is that what you should do?

That is what you should do.

What do you actually do?

The opposite.

And what is the opposite?

You keep quiet.

And why do you keep quiet?

Because offear, because of shyness, because we don't know that we can help. All of this is because of the lack of trust in the authorities. That is why the battered pregnant woman has to take the first step and not us because if not, we get ourselves in big trouble and they are fine. It's just as the saying goes: between family and a married couple, you don't get involved.

There was a clear distinction between what these women perceive as the 'correct' response and what is actually done in practice. The underlying issue here is the perceived privacy of family life, unfortunately summed up in the popular phrase cited above. Prevailing gendered norms and attitudes have negative implications for both raising awareness of the problem and its prevention. This not only silences women's claims to citizenship but closes down a deeper analysis of the problem that transcends the public/private divide. Speaking out risks getting into 'trouble' and shifts responsibility from perpetrator to victim. It is to issues of responsibility and blame that I now turn.

\section{Blame and responsibility}

It is not unusual in accounts of violence for narrators to look for someone to 'blame'. Apportioning blame can help make sense of violence, but also works to silence questions of responsibility and accountability. In defence of their own actions, men repeatedly pointed to their mothers as the figures that 'taught' them how to be men. Many of the interviewees' fathers were absent or themselves abusive. In interviews with men, they often referred to women's violence and its role in reproducing machismo. I was concerned that this not only silenced women's experiences and interpretations of violence, but that it invoked a partial reading of the problem. While talking informally to a group of men in El Boulevar, they stated that violence against men was more of a problem than violence against women in the community: 'Here, the women are terrible', they laughed.

Although a flippant remark, the sentiment implicit in the statement caused me to reflect upon how I was approaching the research. After an initial concern with masculinities, I realised that I needed to speak to women in order to achieve a more comprehensive (and critical) analysis. Scheper-Hughes (1995: 411) argues that there is 'little virtue to fake neutrality in the face of the broad political and moral dramas of life and death'. While this may be more an obvious concern in situations of political conflict, it presents a challenge to all research on violence. It is in this vein that Liebling (2001: 428) reminds us that violence talk is a 'constant form of moral discourse' and researchers make judgements. The process of 'judging' violence is far from straightforward and highly subjective, engaging with issues such as rapport, the researcher's own biography and how well the interviewee presents his/her rationale.

Elsewhere, I have argued that researchers should not situate themselves outside the process of judgement, but should challenge their own feelings and emotions with regards to the research process (Hume 2007a). We must, as Robben (1995) warns, be aware of the pull of 'anthropological seduction' when research participants try to convince us of their 'rightness'. Apportioning blame to women is not incidental. It is suggestive of a tendency among certain groups to blame others in order to deflect attention from their own use of violence and promote their own rationales. In the case of 
violence against women, it is also indicative of social attitudes that trivialise the problem and silence women's own experiences and interpretations. Attitudes that hold women responsible for violence continue to have currency among younger generations. One boy in a school in Soyapango commented in May 2002:

In the whole country there have been a lot of rapes... even of men, even men are raped and [men] look at women all provocative like because women even wear mini skirts and you can see almost everything and that tempts the man and he goes and f...cks her and worse if he is drunk or on drugs, he grabs her more.

Within this logic, women are to blame because of their dress. Men invoke a range of such strategies to justify and excuse their behaviour. Research that fails to explicitly challenge such attitudes risks reaffirming male power. Cavanagh et al. (2001: 695) speak of the 'exculpatory and expiatory discourses' that dominate men's narratives of violence. Central to such narratives is the two-fold objective of 'mitigating and obfuscating culpability while at the same time seeking forgiveness and absolution'. Many interviewees made a distinction between the 'odd slap' and repeated abuse. Key to men's narratives was that they were not the worst. There was usually a case they knew about: a neighbour or friend whose use of violence was more severe. Although some men spoke of the physical and psychological violence they had used, this was often minimised by language - 'problems at home' - or by seeking to explain their behaviour due to the influence of drugs, alcohol or provocation. An important criticism of feminist research on violence is that men impose their own definitions of violence in order to neutralise or minimise women's experience of abuse. Research on women has also highlighted that they too tend to minimise their own subjections to abuse (Kelly and Radford 1990).

As researchers, we must be alert to the power of localised interpretations and be wary of the hegemony of normative explanations. A woman recounts her neighbours' experiences:

Since I have been living here, I know of about three women ... It usually happened because the husband drank. When he came home drunk, he would start to beat her; he threatened her with a machete. I remember one December one of my neighbours came here because he came home about 10 at night. She arrived all bruised because her husband had been hitting her and my mother had her stay here.

(Anon. woman, San Marcos, December 2008)

None of these women reported the abuse to the authorities. It is a challenge for the researcher, then, to separate issues of blame from issues of cause. It is also essential to challenge the widely accepted 'myths' of violence: the normative understandings of violence that people believe to be true (Hume 2008). It is not uncommon for violence against women to be associated directly with the consumption of alcohol and many men and women in the communities blame alcoholism for violence against women and children. The focus on men's drinking, while clearly a problem, obscures the fact that many men use violence without the 'mitigating' effects of alcohol or drugs (Cavanagh et al. 2001). Research shows that out of a total of 361 men who were reported to the authorities, 220 were in a 'normal' condition when they committed violence and 122 had been drinking (Oxfam America 2007: 11). By naming drinking as the cause, alcohol rather than violence becomes the problem. This has particular ramifications for developing strategies to move beyond violence. It also silences the violence embedded in gender relations that marks the experience of many women. Missing from these stories of violence is a critical analysis of men.

\section{Missing men: whose voice counts?}

During my research, I was struck by the apparent routinisation of violence within the family compared with what policymakers often think of as 'real' violence in the streets. Respondents repeatedly assessed violence against women and children as 'normal'. Although the scale and degree of abuse within families is an obvious area for concern, I found its apparent 'normality' even more disturbing. This is more than a linguistic nuance. The positioning of public violences as separate and different has implications for policy.

Feminists have challenged this arbitrary separation between 'real' violence and violence against women (Stanko 1990). The struggle to have domestic abuse and sexual crimes recognised and legislated against has been a central struggle of feminism, yet there is still an implicit minimisation of the effects of such 
violence in relation to its more 'public' forms. The gendered dynamics of 'real' violence are rarely considered in policy debates. Instead, domestic abuse is popularly regarded as 'private' and a problem to be resolved within the context of the family, while the gendered aspects of violence between men is rarely singled out for critical attention.

As in most contexts, in El Salvador it is young men who dominate in statistics of both perpetrators and victims of violence and crime. In the 'talk' of violence, most people seemed to agree that young male gang members were the key protagonists in El Salvador's post-war violence wave (Hume 2007b). Their masculinity and the gendered dimensions of these crimes are rarely problematised, except in specific studies of masculinities (Hearn 1998). While it may be mentioned in passing that youth gangs are predominately made up of young men, this gendered aspect of gang violence is seldom considered worthy of emphasis or analysis (Hume 2007c). Ignoring that men predominate as 'doers' of violence, and also as its principal victims, silences the critical analysis of men's power in relation to women and other men (Hearn 1998).

Throughout the research, men and women alike emphasised that the use and experience of violence appears bound up with dominant notions of what it means to be a man (Hume 2004). Women in a focus group made direct linkages between machismo and violence:

It results in violence against women. Because of their machismo, men think that you can't disrespect them, they lift us up, they push us about, they beat us, and it is all because of their machismo.

(Anon. woman, Ahuachapan, December 2007)

In general terms, all men (and women) interviewed agreed that violence against women was widespread in their neighbourhoods: 'it is rare the home that is not affected by it' (Focus group, Soyapango, March 2002). This exposes an interesting tension. Domestic abuse is not strictly invisible, but it is regarded as private. It is not silent, but silenced. This distinction is important. Most of the women I spoke to testified to having been subjected to violence at the hands of their current or previous partners. One elderly woman in a focus group in Soyapango, declared: 'I no longer have the problem of a husband. He's dead'. This sentiment was shared by other women whom I interviewed, who also no longer had the 'husband problem'. The routinisation of violence can become so entrenched in everyday relations, it is almost expected as an inevitable and culturally sanctioned element of growing up or being a woman. This provokes a different type of silence to simply not speaking about an issue. Women are expected not to make a fuss. As one woman emphasised, 'it is the simple fact of being a woman'.

It is important to challenge how different silences that surround violence are reinforced by political and social structures. Many women are subjected to violence on a daily basis from their fathers, brothers and husbands, not to mention wider society. The degree of violence women are subjected to, however, is not universal. For some, it was part of systematic physical and psychological abuse at the hands of partners, whereas others mentioned specific episodes of physical violence. Despite important changes in legislation, women are still expected to 'keep the peace' with regard to men's use of violence. This is not to say that attitudes are not changing, with more women reporting violence, but challenges remain. The real power of silences lies in the way they naturalise particular understandings of violence that privilege certain groups. The separation of public and private expressions and the disinterest in violence's gendered dynamics not only obscures important characteristics of violence, but silences a deeper analysis of the problem.

\section{Conclusion}

In conclusion, I have argued that it is necessary to foreground the issue of silence as an integral part of research on violence. Silence is more than what is not said about violence. It is also how violence is talked about and the masculinist norms that inform 'violence talk'. I have addressed overlapping issues in this article: the arbitrary separation of violence against women from consideration of 'real' violence; the gaps in our knowledge of violence and the excuses and localised rationales that work to silence and indeed justify women's experiences of abuse. Central to this has been a critical appraisal of men's role in reproducing violence.

In this sense, addressing silence becomes not just a challenge to research but also the scaffolding 
on which knowledge is constructed. Many initiatives that work to end violence against women address precisely the challenge of breaking the silence. Unless we move towards a

\section{Notes}

1 The first period of fieldwork was doctoral research that addressed violence and gender in two low-income communities in Greater San Salvador, while the second project refers to research carried out in conjunction with Oxfam America on women's perceptions of responses to gendered violence in San Marcos and Ahuachapan.

2 I am not suggesting here that there is a singular feminism; much debate has gone into

\section{References}

Aretxaga, B. (1997) Shattering Silence: Women, Nationalism and Political Subjectivity in Northern Ireland, Princeton: Princeton University Press

Caldeira, T. (2000) City of Walls: Crime, Segregation and Citizenship in Sao Paulo, Berkley: University of California Press

Gavanagh, K.; Dobash, R.P.; Dobash, R.E. and Lewis, R. (2001), 'Remedial Work: Men’s Strategic Responses to their Violence against Intimate Female Partners', Sociology 33: 258-81

Cruz, J.M.; Trigueros Arguello, A. and González, F. (1999) El Crimen Violento en El Salvador [Violent Crime in San Salvador], San Salvador: IUDOP/UCA

FESPAD (2008) Consideraciones Generales en Materia de Seguridad Pública Durante la Gestión del Presidente Antonio Saca [General Considerations about Public Security during the Tenure of President Antonio Saca], http://fespad.org.sv/ wordpress/wp-content/uploads/2008/06/ datosviolenciahomicidagestionsaca.pdf (accessed 30 July 2008)

Foucault, M. (1980) A History of Sexuality, Vol. 1, London: Penguin

Hearn, J. (1998) The Violences of Men, London: Sage

Hume, M. (2008) 'The Myths of Violence: Gender, Community and Conflict in El Salvador', Latin American Perspectives 35.5: 59-76

Hume, M. (2007a) '(Young) Men with Big Guns: Reflexive Encounters with Violence in El Salvador', Bulletin of Latin American Research 26.4: 480-96

Hume, M. (2007b) 'Mano Dura: El Salvador Responds to Gangs', Development in Practice 17.6: 725-38 more critical analysis of silence as multidimensional, meaningful and more than just what is not said, our knowledge and actions will always be partial.

highlighting the range of feminist perspectives. For recent critiques, see Jackson (2006) and Stanley and Wise (2000).

3 The United Nations Development Programme (UNDP) has a programme on challenging violence and they maintain a website of research on issues of crime and violence at: www.violenciaelsalvador.org.sv and the Central American Observatory on violence contains state statistics for different types of crime, at: www.ocavi.com

Hume, M. (2007c) 'Unpicking the Threads: Emotion as Central to the Theory and Practice of Researching Violence', Women's Studies International Forum 30.2: 147-57

Hume, M. (2004) ' "It's as if you Don't Know Because you Don't do Anything About it": Gender and Violence in El Salvador', Environment and Urbanization 16.2: 63-72

Jackson, C. (2006) 'Feminism Spoken Here: Epistemologies for Interdisciplinary Development Research', Development and Change 37.3: 1-23

Kelly, L. (1988) Surviving Sexual Violence, Minneapolis: University of Minnesota Press

Kelly, L. and Radford, J. (1990) “"Nothing Really Happened": The Invalidation of Women's Experiences of Sexual Violence', Critical Social Policy 10.30: 39-53

Liebling, A. (2001) 'Allegiance and Ambivalence. Some Dilemmas in Researching Disorder and Violence', British Journal of Criminology 41.3: 421-30

Oxfam America (2007) 'Situación de la Violencia De Género y su Prevención' ['Context of Gender Violence and its Prevention: Campaign for the Prevention of Gender Violence'], Campaña de Prevención de la Violencia de Género, San Salvador: Oxfam America

Pearce, J. (1998) 'From Givil War to "Civil Society": Has the End of the Cold War Brought Peace to Central America?', International Affairs 74.3: 587-615

Robben, A. (1995) 'The Politics of Truth and Emotion among Victims and Perpetrators of Violence', in C. Nordstrom and A. Robben 
(eds), Fieldwork Under Fire: Contemporary Studies of Violence and Survival, Berkeley: University of California Press

Scheper-Hughes, N. (1995) 'The Primacy of the Ethical: Propositions for a Militant

Anthropology', Current Anthropology 36.3: 409-20

Shrader, E. (2001) Methodologies to Measure the Gender Dimensions of Crime and Violence, Washington DC: World Bank, Gender Unit,
Poverty Reduction and Economic Management, Latin American and Caribbean Region Stanko, E.A. (1990) Everyday Violence: How Women and Men Experience Sexual and Physical Danger, London: Pandora

Stanley, L. and Wise, S. (2000) 'But the Empress Has No Clothes!: Some Awkward Questions about the "Missing Revolution" in Feminist Theory', Feminist Theory 1.3: 261-88 